\title{
Human Resource Management Of Bureaucracy In Indonesia: Is It True That Job Satisfaction Increases Employee Performance ?
}

\author{
Meimoon Ibrahim ${ }^{1}$, Ilyas Lamuda ${ }^{2}$ \\ ${ }^{1}$ Economic Faculty Universitas Gorontalo, Indonesia \\ ${ }^{2}$ Universitas Gorontalo. Indonesia \\ E-mail : meimoonibrahim@yahoo.com
}

\begin{abstract}
Objective: This study aims to analyze how the effect of leadership variables on employee performance with job satisfaction as intervening in the provincial government of Gorontalo-Indonesia.

Methods: The approach used is explanatory research, pattern of research that seeks to explain the relationship of variables referred so that the relationship of these variables can be tested with a quantitative approach and hypothesis testing used is the method of Structural Equation Modeling, with analytical tools of Loading Factor and Critical Ratio which is preceded by a validity test and reliability test. The sample was drawn randomly according to representative samples at the level of the position group as many as $5 \%$ employee population of the Provincial it.

Results ; The results of the study show that leadership style has a positive and significant influence on job satisfaction and leadership style has an effect on employees' performance, but job satisfaction has negative and non-significant effect on employee performance. Conclusion; Expected that this research could also be developed in other fields or a wider scope and not only because each region has different characteristics. So it is recommended that policy makers as bureaucratic managers to pay more attention to job satisfaction factors in order to further improve employee performance.
\end{abstract}

Keywords: Leadership, Job Satisfaction, Employee Performance

\section{Introduction}

Human resource is a production factor that influences other production factors such as machine, capital, material, and method. Therefore, organizations are demanded to manage their human resources properly for the continuance and development of the organizations themselves, and the success of an organization in achieving its objectives is determined by leadership. Likewise with leadership in government organizations that many factors can determine the success of leaders in achieving their goals. One of them is a leadership style that is the behavior used by a leader in influencing his employees or followers. The application of leadership styles in government organizations in the regions is more complex because employees or staffs led have educational backgrounds and fields of work, even different mental conditions. Therefore leadership in the organization is very important and it is expected that in carrying out their duties he must be qualified and competent as it was first introduced by McClelland in 1961, which is a fundamental characteristic possessed by someone who will directly influence or predict good performance. Because the work of an employee interacts directly with the community. So that competent leaders are needed. Because the success of an organization in achieving its objectives is largely determined by the quality of leadership in the organization, in the sense that leadership entities play a very important and dominant role in carrying out all leadership functions. James Mc Mahon in (Dale Timpe, 1988), states that employees need challenging tasks, and the involving of them that they are part of the activity. This need can be met by managers or leaders through effective delegation.

Organizations that succeed in their mission have a main characteristic that distinguishes them from unsuccessful organizations, namely dynamic and effective leadership. From various aspects, 
the search for people who have the ability to lead organizations effectively, not only limited to the business but also seen in various sectors such as government, education and other forms of organization.

Therefore the attitude of the leader as the main task in organization is to take a leadership style that satisfies all employee needs while achieving the goals and objectives of the organization.

States that leadership style is a typical pattern of behavior shown by leaders when dealing with members of a group. The leadership style is usually described as autocratic, participatory, taskoriented and human-oriented. This means that leadership style is behavior and strategy as a result of a combination of the motto of life, skills, character, and attitude that is often applied by a leader when trying to influence the performance of his members. The application of leadership styles used by leaders can reduce job satisfaction of employees. (Dubrin, 1998)

Job satisfaction is a pleasant psychological condition felt by workers or employees in a work environment for their role in the organization. As stated by Tiffin that job satisfaction is the relationship between the attitude of employees to their own work, work situations and cooperation between leaders and employees.(Herzberg, 1974) states that there are certain factors in the workplace that cause job satisfaction, while in other parts there are also other factors that cause dissatisfaction. In other words, satisfaction and job dissatisfaction are related to one another.

Job satisfaction is not only caused by the existence of a comfortable work environment, high rewards but also caused by the existence of a good leadership style because the comfortable environment of high reward if the treatment of leaders towards members is not good then the psychological condition of employees will not be good, so that this is expected to improve employees' performance.
Employee performance is a term derived from Job Performance or actual performance, namely work performance or actual achievement achieved by someone. (Douglas, 2011) stated that employees' performance (work performance) is the work of quality and quantity achieved by an employee in carrying out his duties in accordance with the responsibilities given to him. So the research question is: Does the leadership style have a positive and significant influence on employee performance with job satisfaction of employees as intervening variables in the Provincial Government of Gorontalo.

This research was inspired by Research (Babalola, 2016) with research results stating that: Although organizational commitment and job performance are essential for the survival of an organization, yet scanty attention is paid to simultaneous investigation of these variables. This study set to investigate the influence of supervisor-employee relationship, perceived leadership style, and job satisfaction on organizational commitment and job performance. Two hundred and fifty-five employees of media employees are conveniently sampled with ages ranging from 20 to 57 years with a mean of 34.29 years. Stepwise multiple regression analysis was employed to test the working hypotheses.Stepwise regression analysis reveals three steps in the prediction of organizational commitment and job performance respectively. With the third steps showing that job satisfaction $(\beta=0.53 ; \mathrm{p}<.001)$; supervisor-subordinate relationship $(\beta=$ $0.41 ; \mathrm{p}<.001)$ and laissez-faire leadership styles $(\beta=0.38 ; \mathrm{p}<.001)$ as predicting organizational commitment with $49.7 \%$ variance is explained; while with job performance, $34.8 \%$ of variance explained the variables of working experience $(\beta=$ 0.54; $\mathrm{p}<.001)$; education $(\beta=0.31 ; \mathrm{p}<$ $.01)$ and transformational leadership styles $(\beta=-0.22 ; p<.05)$. This finding has implications for employee retention, 
performance management and incentive strategy.

The research of (Yiing and Ahmad, 2009), The moderating effects of organizational culture on therelationships between leadership behaviour and organizational commitment and between organizational commitment and job saticfaction and performance Faculty of Business and Accountancy. With research variables namely organizational culture, leadership behavior, organizational commitment, inter-organizational commitment, job satisfaction and performance. The analysis tool used is Structural Equation Modeling (SEM). The results of the study found that the directive leadership model had a positive effect on job satisfaction and also had a positive effect on organization performance. The research of (Khuzaeni, Idrus, Djumahir, 2013) The Influence of work Culture, Work Stress to the Job Satisfaction and Employees Performance in the State Treasury Service Office in Jakarta, Indonesia. The variables studied are: Work culture, work stress, job satisfaction, and employees' performance. The method of analysis using PLS with the results of the study states that: work culture does not affect job satisfaction. Job stress has no effect on job satisfaction. Work culture influences employee performance. Job stress has no effect on employee performance. Job satisfaction has no effect on performance. The implication of this research is to build a strong work culture and reduce work stress and improve job satisfaction which ultimately improves employee performance. The research of (Kertiriasih, Sujana, \& Suardika, 2018)The Effect of Leadership Style to Job Satisfaction, Employee Engagement and Employee Performance (Study at PT. Interbat, Bali, Nusra, and Ambon. They do research with research variables such as leadership style, job satisfaction, employee involvement and performance. The analysis tool is SEM and data processing using PLS. The results of this study indicate that found leadership style that has a positive and significant effect on job satisfaction, but leadership style does not have a significant influence on employee involvement, leadership style does not significantly influence employee performance, but leadership style influences employee performance through work mediation and employee involvement, Job satisfaction has a positive and significant impact on employee involvement, employee involvement has a positive and significant impact on employee performance and employee involvement has a positive and significant impact on employee performance. The research of (Badreya Al-Jenaibi, 2014) The Impact of Leadership Style on Employee Job Satisfaction. The variables studied were leadership style and job satisfaction. The analysis method uses qualitative methods in which case analysis techniques are used to analyze the UAE construction sector. Questionnaires were distributed among 300 leaders from various places, which were then analyzed based on previous research. The findings show the consultative and consensus leadership styles prevalent in the UAE construction sector, and furthermore, that leadership greatly influences job satisfaction of employees. Because effective leaders have self discipline, integrity, courage, firmness, sensitivity to others, humility, and selflessness, they understand the needs and feelings of their followers, and thus have a unique position to motivate the people they lead.

The research of (Vigoda-Gadot, 2007)), Leadership Style Organizational Politics Employee Performance. The research variables are: leadership style, organizational policy, employee performance using analysis tools of Structural Equation Modeling (SEM). The results of the study are that leadership style has a direct influence on employee performance, and there is an indirect influence of leadership style on employee 
performance through organizational policy variables.

\section{Methods}

The pattern used is explanatory research, namely the pattern of research that seeks to explain the relationship of variables referred to as formulated in the formulation of hypotheses so that the relationships between variables: Leadership Style (X) and Job Satisfaction (Y1) and employee performance can be tested with quantitative approaches. Correlation research is the relationship between variables. This variable that has connectivity is a survey model designed to discuss things that affect employee performance. The survey model in addition can be used to describe conditions with established criteria, can also be used to investigate the differences in condition and to test hypotheses.

Data analysis is done by using statistics, both descriptively and inferentially. For the purposes of testing the hypothesis, the Structural Equation Modeling (SEM) method is used with Loading Factor and Critical Ratio Generalization performed on the population in the SEM model developed and found based on the discussion of research results in studying or looking for causal relationships between independent variables or leadership style predictors, and job satisfaction as a variable between intervening variables on non-independent variables on employee performance. The relationship can be established that the Measurement Model of the Conceptual Diagram of the Path Model is as Figure 1.

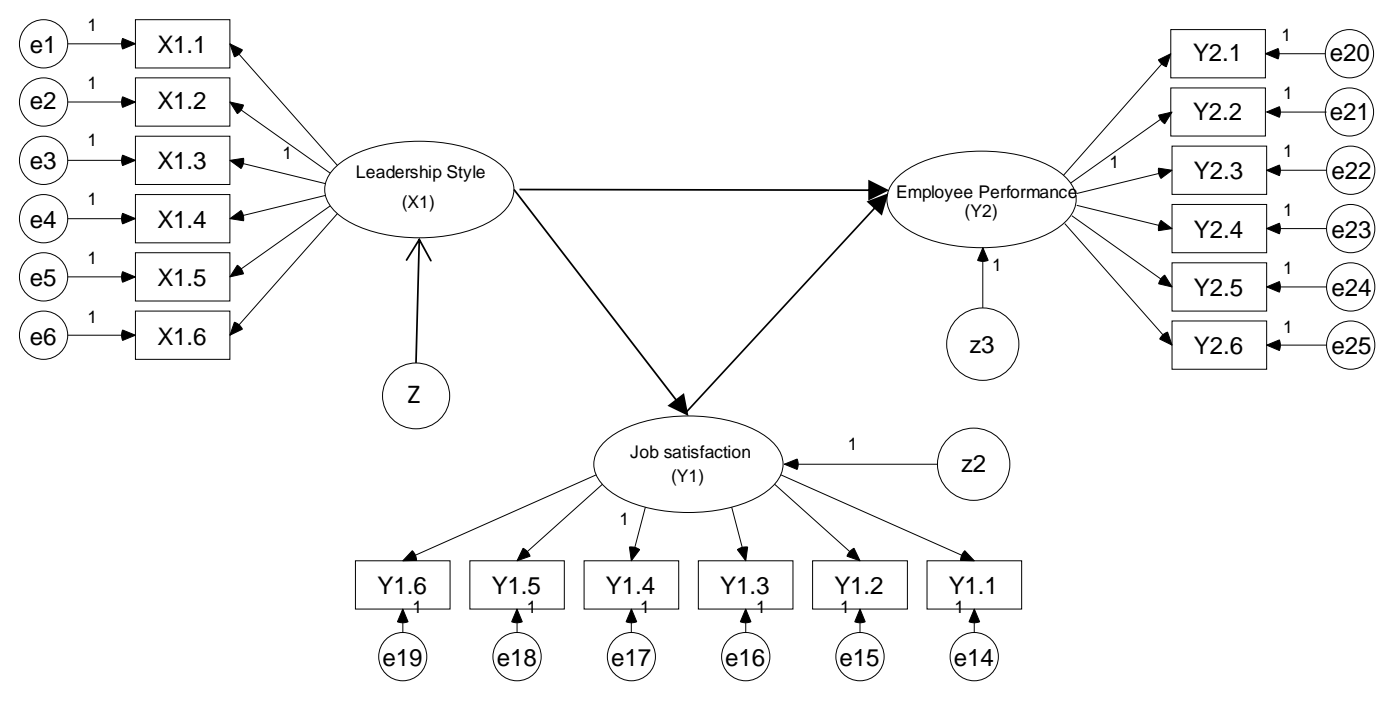

Figure 1. Conceptual Model Path Diagram

The population in this study has the general characteristics of employees who are employees of the regional government (State Civil Apparatus) the Gorontalo province that chose in this study was employees with groups I, II and III of the Regional Government of Gorontalo Province. By reason of population selection that employees of this group are employees who often experience the treatment of the variables under study.

Samples are drawn randomly based on the sample size for structural equation models (SEM) at least 200 observations the population composition and sample seen as in Table 1.

Table 1: Population Composition and Sample

\begin{tabular}{|l|l|l|}
\hline Groups & Population & Sample \\
\hline
\end{tabular}




\begin{tabular}{|l|l|l|}
\hline I & 21 & 1 \\
\hline II & 842 & 42 \\
\hline III & 3.134 & 157 \\
\hline Total & 3.997 & 200 \\
\hline
\end{tabular}

\section{Research Results}

Test Validity and Reliability of variables can be presented in the following tables according to each variable at Table 2 shows that all question items for leadership style variables (X1) have a correlation value which is greater than 0.3 . Whereas the alpha coefficient is 0.744 it means that the question item for the leadership style variable (X1) is valid and reliable for further testing.

Table 2.: Test the Validity and Reliability of Leadership Style Variables (X1)

\begin{tabular}{|c|c|c|c|c|}
\hline \multirow[b]{2}{*}{ Variable } & \multirow[b]{2}{*}{ Indicator } & \multicolumn{2}{|l|}{ Validity } & \multirow[b]{2}{*}{$\begin{array}{l}\text { Alpha } \\
\text { coefficient }\end{array}$} \\
\hline & & $\begin{array}{l}\text { Correlation } \\
\text { (r) }\end{array}$ & Probability (p) & \\
\hline \multirow{6}{*}{$\begin{array}{l}\text { Leadership } \\
\text { Style } \\
\text { (X1) }\end{array}$} & $\mathrm{X} 1.1$ & 0.495 & 0.000 & \multirow{6}{*}{0.744} \\
\hline & $\mathrm{X} 1.2$ & 0.534 & 0.000 & \\
\hline & $\mathrm{X} 1.3$ & 0.653 & 0.000 & \\
\hline & $\mathrm{X} 1.4$ & 0.669 & 0.000 & \\
\hline & $\mathrm{X} 1.5$ & 0.680 & 0.000 & \\
\hline & X1.6 & 0.619 & 0.000 & \\
\hline
\end{tabular}

Fruther Table 3 shows that all question items for the variable of Job Satisfaction (Y1) have a correlation value which is greater than 0.3 . Whereas the alpha coefficient is 0.735 it means that the question item for the variable of Job Satisfaction (Y1) is valid and reliable for further testing.

Table 3: Test Validity and Variables Reliability of Job Satisfaction (Y1)

\begin{tabular}{|c|c|c|c|c|}
\hline \multirow[b]{2}{*}{ Variable } & \multirow[b]{2}{*}{ Indicator } & \multicolumn{2}{|l|}{ Validity } & \multirow[b]{2}{*}{$\begin{array}{l}\text { Alpha } \\
\text { coefficient }\end{array}$} \\
\hline & & $\begin{array}{l}\text { Correlation } \\
\text { (r) }\end{array}$ & $\begin{array}{l}\text { Probability } \\
\text { (p) }\end{array}$ & \\
\hline \multirow{6}{*}{$\begin{array}{l}\text { Job } \\
\text { satisfaction } \\
\text { (Y1) }\end{array}$} & Y1.1 & 0.453 & 0.000 & \multirow{6}{*}{0.735} \\
\hline & Y1.2 & 0.601 & 0.000 & \\
\hline & Y1.3 & 0.671 & 0.000 & \\
\hline & Y1.4 & 0.732 & 0.000 & \\
\hline & Y1.5 & 0.643 & 0.000 & \\
\hline & Y1.6 & 0.441 & 0.000 & \\
\hline
\end{tabular}

Table 4 needs that all question items for Employee Performance variable (Y2) have a correlation which is value greater than 0.3 , and the alpha coefficient is 0.747 .
Thus it means that the question item for variable employee performance (Y2) is valid and reliable for further testing.

Table 4: Test the Validity and Variable Reliability of Employee Performance (Y2)

\begin{tabular}{|l|l|l|l|}
\hline Variable & Indicator & Validity & $\begin{array}{l}\text { Alpha } \\
\text { coefficient }\end{array}$ \\
\hline
\end{tabular}




\begin{tabular}{|l|l|l|l|l|}
\hline & & Correlation $(\mathrm{r})$ & $\begin{array}{l}\text { Probability } \\
(\mathrm{p})\end{array}$ & \\
\hline \multirow{4}{*}{$\begin{array}{l}\text { Employee } \\
\text { Performance } \\
(\mathrm{Y} 2)\end{array}$} & $\mathrm{Y} 2.1$ & 0.502 & 0.000 & \\
\cline { 2 - 4 } & $\mathrm{Y} 2.2$ & 0.641 & 0.000 & \\
\cline { 2 - 4 } & $\mathrm{Y} 2.3$ & 0.695 & 0.000 & \multirow{4}{*}{0.747} \\
\cline { 2 - 4 } & $\mathrm{Y} 2.4$ & 0.753 & 0.000 & \\
\cline { 2 - 4 } & $\mathrm{Y} 2.5$ & 0.529 & 0.000 & \\
\cline { 2 - 4 } & $\mathrm{Y} 2.6$ & 0.566 & 0.000 & \\
\hline
\end{tabular}

The evaluation of the proposed model shows that the model evaluation of the construct as a whole produces values above critical except for the value of AGFI, TLI, CFI and RMSEA but the score is close to the critical value so that overall the model is in accordance with the data, so that conformity tests can be carried out the next model.
Variables that can be used as indicators of leadership style variables (X1), are shown from the value of loading factors or lamda coefficients of each indicator presented in Table 5 with the amount of weight factors that must be greater than 0.40 so that dimensions and indicators of weight the factor must be less than 0.40 is not included in the model.

Table 5: Criteria Evaluation of Goodness of Fit Indices of leadership style (X1)

\begin{tabular}{|l|l|l|l|}
\hline $\begin{array}{l}\text { Goodness of fit } \\
\text { index }\end{array}$ & Cut-off Value & Model Results * & Description \\
\hline$\chi^{2}-$ Chi-square & $\begin{array}{l}\text { Expected to be } \\
\text { small }\end{array}$ & $\begin{array}{l}15,293 \\
(9=16,91898)\end{array}$ & Less Good \\
\hline Sign.Probability & $\geq 0.05$ & 0.083 & Good \\
\hline CMIN/DF & $\leq 2.00$ & 1,699 & Good \\
\hline RMSEA & $\geq 0.08$ & 0.080 & Good \\
\hline GFI & $\geq 0.90$ & 0.955 & Good \\
\hline AGFI & $\geq 0.90$ & 0.896 & Less Good \\
\hline TLI & $\geq 0.94$ & 0.863 & Less Good \\
\hline CFI & $\geq 0.94$ & 0.918 & Less Good \\
\hline
\end{tabular}

Table 6 Criteria Evaluation for Goodness of Fit Indices of Job Satisfaction (Y1)

\begin{tabular}{|l|l|l|l|}
\hline Goodness of fit index & Cut-off Value & Model Result* & Description \\
\hline$\chi^{2}-$ Chi-square & Expected to be small & $\begin{array}{l}11,005 \\
(9=16,91898)\end{array}$ & Good \\
\hline Sign.Probability & $\geq 0.05$ & 0.275 & Good \\
\hline CMIN/DF & $\leq 2.00$ & 1,223 & Good \\
\hline RMSEA & $\leq 0,08$ & 0.045 & Good \\
\hline GFI & $\geq 0.90$ & 0.966 & Good \\
\hline AGFI & $\geq 0.90$ & 0.922 & Good \\
\hline TLI & $\geq 0.95$ & 0,952 & Good \\
\hline CFI & $\geq 0.95$ & 0,971 & Good \\
\hline
\end{tabular}

From the evaluation of the model proposed shows that the evaluation of the model towards the construct as a whole produces a value above critical which indicates that the model is in accordance with the data, 
so that the suitability test of the next model can be carried out.

Furthermore, it can be seen in the following table regarding the evaluation of the criteria for goodness of fit indices of employee performance:

Table 7: Criteria Evaluation for Goodness of Fit Indices of Employee Performance (Y2)

\begin{tabular}{|l|l|l|l|}
\hline $\begin{array}{l}\text { Goodness of fit } \\
\text { index }\end{array}$ & Cut-off Value & $*$ Model Results & Description \\
\hline$\chi^{2}-$ Chi-square & $\begin{array}{l}\text { Expected to be } \\
\text { small }\end{array}$ & $\begin{array}{l}14,129 \\
(9=16,91898\end{array}$ & Good \\
\hline Sign.Probability & $\geq 0.05$ & 0.118 & Good \\
\hline CMIN/DF & $\leq 2.00$ & 1.570 & Good \\
\hline RMSEA & $\leq 0,08$ & 0.072 & Good \\
\hline GFI & $\geq 0.90$ & 0.955 & Good \\
\hline AGFI & $\geq 0.90$ & 0.895 & Good \\
\hline TLI & $\geq 0.95$ & 0.902 & Good \\
\hline CFI & $\geq 0.95$ & 0.941 & Good \\
\hline
\end{tabular}

The evaluation of the proposed model shows that the evaluation of the model for the construct as a whole produces values above critical except for CMIN / DF and TLI but the scores of both have approached the critical value indicating that the model is in accordance with the data, so that the model conformity test can be carried out.

Table 8: Loading Factors ( $\lambda$ ) measurement of variables of leadership style (X1)

\begin{tabular}{|l|l|l|l|l|}
\hline $\begin{array}{l}\text { Variable } \\
\text { Indicator }\end{array}$ & $\begin{array}{l}\text { Loading } \\
\text { Factor }(\boldsymbol{\chi})\end{array}$ & Critical Ratio & $\begin{array}{l}\text { Probability } \\
(\boldsymbol{p})\end{array}$ & Description \\
\hline X1.1 & 0,29 & 2,327 & 0,02 & Significant \\
\hline X1.2 & 0,343 & 2,69 & 0,007 & Significant \\
\hline X1.3 & 0,58 & 4,455 & 0 & Significant \\
\hline X1.4 & 0,615 & FIX & 0 & Significant \\
\hline X1.5 & 0,625 & 3,575 & 0 & Significant \\
\hline X1.6 & 0,52 & 3,278 & 0,001 & Significant \\
\hline
\end{tabular}

The value of $\mathrm{t}$ table at level of $5 \%$ with the amount of data is $200=1.98$

Loading faktor $(\lambda)$ measurement of variables of leadership style (X1) in Table 8 shows the results of hypothesis testing of the measurement model of the leadership style (X1) of each dimension and indicator that explains the construct, especially the latent (unobserved variable) dimension of force (0.461) which consists of indicators prohibiting members or follwers from leaving the office and leadership giving direction, autocratic style dimension (0.426) which consists of indicators of being empathetic to employees and acting as a catalyst for change, affiliate style dimensions (0.516) consisting of indicators building emotional bonds with employees and placing employees as the main thing, speed style dimension ( 0.559$)$ which consists of indicators telling employees to do / do a job like what they are doing now and being motivated to achieve a goal, dimensions of democratic style (0.687) represented by indicators that are easy to collaborate with subordinates and leaders respond to members or follwers, and the 
coach style dimension (0.536), which is represented by an indicator to help employees identify their strengths and weaknesses, all of which have a factor value which is greater than 0.40 so that they are included in the next testing.

Table 9: Loading Factors $(\lambda)$ measurement of job satisfaction variables (Y1)

\begin{tabular}{|l|l|l|l|l|}
\hline Variable Indicator & $\begin{array}{l}\text { Loading } \\
\text { Factor }(\boldsymbol{\chi})\end{array}$ & Critical Ratio & $\begin{array}{l}\text { Probability } \\
(\mathbf{p})\end{array}$ & Description \\
\hline Y1.1 & 0,331 & 2,735 & 0,006 & Significant \\
\hline Y1.2 & 0,536 & 3,988 & 0 & Significant \\
\hline Y1.3 & 0,573 & 3,923 & 0 & Significant \\
\hline Y1.4 & 0,699 & FIX & 0 & Significant \\
\hline Y1.5 & 0,529 & 4,057 & 0 & Significant \\
\hline Y1.6 & 0,213 & 1,819 & 0 & Significant \\
\hline
\end{tabular}

Loading factor $(\lambda)$ the measurement of the job satisfaction variable (Y1) in Table 9 shows the results of hypothesis testing of the measurement model of job satisfaction variables (Y1) of each indicator that explains the construct, especially the latent variable (unobserved variable) $(\mathrm{Y} 1.1=0.331)$, loves his job $(\mathrm{Y} 1.2=0.536)$, positive work morale $(\mathrm{Y} 1.3=0.573)$, work discipline $(\mathrm{Y} 1.4=$ $0.699)$, work performance $(\mathrm{Y} 1.5=0.529)$, work productivity $(\mathrm{Y} 1.6=0.213)$ so that all included in the next testing.

Variables that can be used as indicators of employee performance variables (Y2), are indicated by the value of loading factors or lamda coefficients of each indicator presented in Table 10, provided that the weight of the factor must be greater than 0.40 so that dimensions and indicators of weight the factor must be less than 0.40 is not included in the model.

Table 10: Loading Factors ( $\lambda$ ) measurement of employee performance variables (Y2)

\begin{tabular}{|l|l|l|l|l|}
\hline Variable Indicator & $\begin{array}{l}\text { Loading } \\
\text { Factor }(\boldsymbol{\chi})\end{array}$ & Critical Ratio & $\begin{array}{l}\text { Probability } \\
(\mathbf{p})\end{array}$ & Description \\
\hline Y2.1 & 0,331 & 2,735 & 0,006 & Significant \\
\hline Y2.2 & 0,536 & 3,988 & 0 & Significant \\
\hline Y2.3 & 0,573 & 3,923 & 0 & Significant \\
\hline Y2.4 & 0,699 & FIX & 0 & Significant \\
\hline Y2.5 & 0,529 & 4,057 & 0 & Significant \\
\hline Y2.6 & 0,213 & 1,819 & 0,069 & Not Significant \\
\hline
\end{tabular}

Loading factor $(\lambda)$ measurement of employee performance variables (Y2) in Table 10 shows the results of hypothesis testing of the employee performance variable measurement model (Y2) of each indicator that explains the construct, especially the latent variable (unobserved variable) from the indicator of work quantity $(\mathrm{Y} 2.1=0.331)$, the quality of work (Y2.2 $=0.536)$, number of working hours $(\mathrm{Y} 2.3=0.573)$, creativity $(\mathrm{Y} 2.4=$ $0.699)$, level of accuracy (Y2.5 $=0.529)$ and work results according to policy (Y2.6 $=0.213$ ) so that all are included in next test. So that the model test results are obtained as Figure 2. 


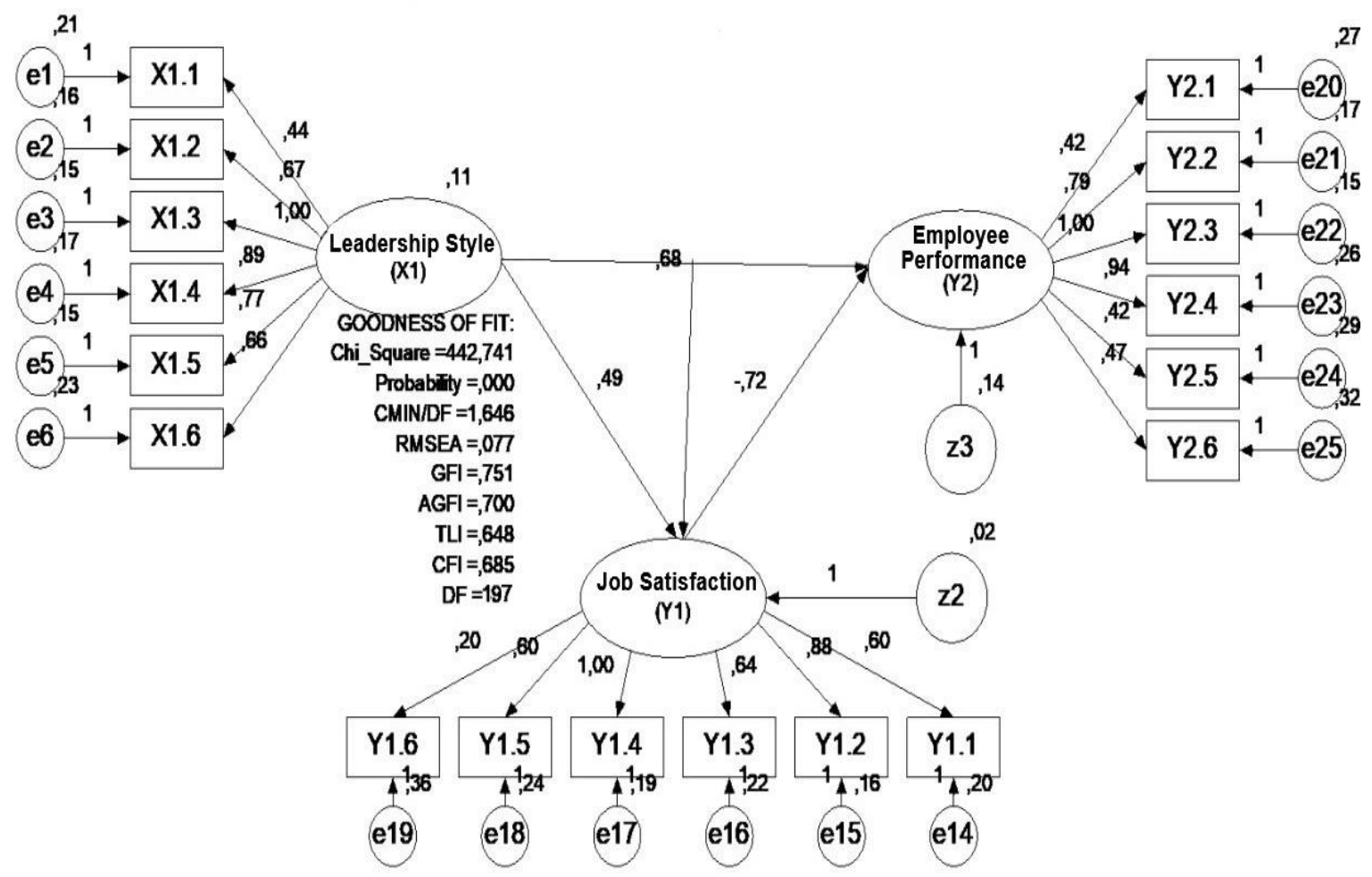

Figure 2

Measurement of Factors and Model Test Results in the relationship between leadership style (X1), job satisfaction (Y1) on employee performance (Y2)

Table 11 below is a hypothesis testing by comparing the calculated value with the ttable value, if the $\mathrm{t}$-count value is greater than $\mathrm{t}$-table, then the relationship between the significant variables and can be further analyzed. On degree of freedom $(\mathrm{df})=243$ the value of T-table ( $\alpha=5 \mathrm{a}$ ) is 1.98 . The test results are presented in the following table:

Table 11

Testing the Hypothesis of Test The model of the relationship between leadership styles (X1), job satisfaction (Y1) on employee performance (Y2)

\begin{tabular}{|c|c|c|c|c|c|c|c|c|}
\hline $\mathbf{H}$ & \multicolumn{3}{|c|}{ Type of Influence } & $\begin{array}{l}\text { Loading } \\
\text { Factor }\end{array}$ & CR & Prob & Description & $\begin{array}{l}\text { Conclusio } \\
\mathrm{n}\end{array}$ \\
\hline $\begin{array}{l}\mathrm{H} \\
1 \\
\end{array}$ & $\begin{array}{l}\text { job } \\
\text { satisfaction } \\
\text { (Y1) }\end{array}$ & $<-$ & $\begin{array}{l}\text { leadership } \\
\text { (X1) }\end{array}$ & 0,292 & 2,025 & $\begin{array}{l}0.04 \\
3 \\
\end{array}$ & Significant & $\begin{array}{l}\text { Accept the } \\
\text { hypothesis }\end{array}$ \\
\hline $\begin{array}{l}\mathrm{H} \\
2\end{array}$ & $\begin{array}{l}\text { employee } \\
\text { performanc } \\
\text { e (Y2) }\end{array}$ & $<-$ & $\begin{array}{l}\text { leadership } \\
\text { (X1) }\end{array}$ & 0,793 & 2,962 & $\begin{array}{l}0.00 \\
3\end{array}$ & Significant & $\begin{array}{l}\text { Accept the } \\
\text { hypothesis }\end{array}$ \\
\hline $\begin{array}{l}\mathrm{H} \\
3\end{array}$ & $\begin{array}{l}\text { employee } \\
\text { performanc } \\
\text { e (Y2) }\end{array}$ & $<-$ & satisfaction & $-0,491$ & - & $\begin{array}{l}0.06 \\
4\end{array}$ & $\begin{array}{l}\text { Not } \\
\text { Significant }\end{array}$ & $\begin{array}{l}\text { Reject the } \\
\text { Hypothesis }\end{array}$ \\
\hline
\end{tabular}

Description 
* Significant at level $5 \%$, value of t-table $(\alpha=5 \%)=1.98$

Source: processed data

\section{Discussion}

\section{Effect of Leadership Style on Job Satisfaction}

Leadership Style has a positive and significant influence on Job Satisfaction this coefficient shows that increasing leadership style will increase job satisfaction.

To answer the formulation of problem, then partially can be observed from the results of SEM analysis in this study which shows a positive influence between Leadership Style (X1) on employee Job Satisfaction (Y1) which is characterized by a positive path coefficient. Thus it can be concluded that Leadership Style (X1) gives direct role in employee job satisfaction (Y1) in the Regional Government of Gorontalo Province.

Then the direct effect between Leadership Style (X1) and Job Satisfaction (Y1) with positive direction is 0.292 and has an indirect effect of 0.301 so that the total effect which is the sum of direct effects and indirect effects is 0.593. Thus it can be concluded that the hypothesis stating that the Leadership Style has a positive and significant effect on Job Satisfaction in the Gorontalo Provincial Government is proven or supported by facts. The results of this study support the results of previous studies, namely Chester A. Schrisheinm, et al. in (Dale Timpe, 1988)) which states that Leadership Style can influence and direct the actions of employees in an effort to utilize human, material, and technological resources to achieve organizational goals effectively. As a leader in the organization, it is necessary to pay attention to the Leadership Style used in directing employees so that they can achieve better work. This leadership style can make employees act to receive leader's direction, responsibility and work according to their duties. The leadership style of a leader will greatly affect the working conditions of employees, which will relate to how employees receive a leadership style, happy or not, like it or not, which ultimately motivates employees to do their jobs well. Therefore, the Regional Government of Gorontalo Province needs a leader who, besides having personal abilities, is also able to read the conditions of his employees and his work environment. In this case the maturity of employees is directly related to the right leadership style to be applied, so that leaders obtain adequate adherence or influence. This research supports previous research, namely research of (Kertiriasih et al., 2018), (Badreya Al-Jenaibi, 2014)), but refused research of (Khuzaeni, Idrus, Djumahir, 2013)

\section{Effect of Leadership Style on Employee Performance}

Leadership style has a positive and significant influence on employee performance with $\mathrm{P}=0.003(<0.05)$ and value of $\mathrm{CR}(t$ count $>t$ table $(2.962>$ 1.98 ) and loading factor of 0.793 , this coefficient shows that by increasing leadership style it will improve employee performance.

The results of SEM analysis show that leadership styles have a significant influence on employee performance which is characterized by path coefficients that can be seen from the value of standardized regression weight of 0.793 . Thus it can be concluded that leadership style has a positive influence on employee performance. The direct effect between Leadership Style (X1) and Employee Performance (Y2) with a positive direction is 0.292 and has an indirect effect with a negative direction of -0.314 so that the total effect which is the sum of direct effects and indirect effects is 0.650 . Thus it can be concluded that the hypothesis which states that leadership style has a significant positive effect on the 
performance of employees in the Provincial Government of Gorontalo is proven or supported by facts.

(Siagian, 1999), states that not all leadership styles applied in carrying out their activities have the same effect on achieving organizational goals, in this case the use of inappropriate leadership styles will actually reduce employee performance. In this case according to (Waldman, D. A., \& Yammarino, 1999) said that leadership styles will influence organizational performance but are influenced by situations. In this study the influence of leadership style on performance is strongly influenced by job satisfaction of employees. The leadership style is individual oriented, but without a relationship with job satisfaction, this individual-oriented leadership style will not be effective and the performance of employees will actually decrease. The influence of leadership style on performance also shows that the leadership style used by the leadership. Employee participation in contributing to the organization needs to be continuously optimized to improve employee performance.

The findings of this study compared with previous studies have differences in objects in the Gorontalo Provincial Government that are closely related to accuracy and skills that require a fairly good emotional atmosphere, and challenges to providing quality results, besides that members are involved in decision making. Therefore, leaders should involve employees in the process by continuously training and guiding employees so that they can get quality work. Besides that, the leader conducts a study work on the workings of employees which is a guideline to direct employees to increase their work. Leaders when using autocratic leadership style and two-dimensional speed style are dominant in leadership style, it is difficult for subordinates to accept such conditions because psychologically or emotionally they are depressed because demands must be obedient to regulations, narrow and rational specializations so employees feel that they are a part of the organization, so that it has a place for feeling and its ability to be creative. The use of leadership style by someone is with the aim to succeed optimally. What they need and how to improve their work as optimally as possible so that leadership and employees get mutual success, for that leadership style that is able to combine force style, autocratic style, affiliate style, style of speed and style of the coach in a professional and proportional manner. Coercive-style leaders always:

- If the leader gives the task to the employee, then the employee must complete the task in accordance with the way desired by the leader.

- If the leader gives the task they are always encouraged to achieve challenging work performance.

- If they face a complicated problem, they can solve the problem correctly.

- Having competence in emotional control. Autocratic-style leader always:

- Having strong confidence to be able to complete their tasks properly.

- Direct employees to the organization's vision.

- Having the ability to feel the emotions of employees to achieve organizational goals.

- Directly involved with what is felt by employees

- Having the ability to direct employees so that they can implement their new ideas and ways of completing work

- Having the ability to create new ideas or ways to complete a job.

Leaders who are in the style of Affiliates always:

- Maintain their harmony with their employees.

- Assume that the employee is the most valuable asset for the organization.

- Having the ability to feel the emotions of employees

- Directly involved with what concerns the employee. 
- Have the ability to describe and explain their messages to employees

Democratic leaders always.

- Involve employees in decision making.

- Having the ability to communicate well with employees.

- Responding and appreciating ideas, opinions and suggestions from employees.

- Able to collaborate and build work teams. Leaders who have an Acceleration style always:

- Establish high work standards that must be achieved by employees.

- Always tell employees to do a job like what the leader does.

- Have the ability to regulate themselves and be accountable to themselves for what they do.

- Have a strong desire to achieve challenging work standards.

Coach-style leaders always:

- Strong and has the ability to understand and control the emotions of employees.

- Give employees the opportunity to try their own ideas.

- Has the ability to feel the emotions of employees.

- Having the ability to improve the ability of employees by providing feedback and instructions on methods for completing the task.

- Directly involved with what concerns by the employee.

- Having the ability to understand and control the emotions of employees so that they are always passionate and have high work standards.

This study supports the findings of previous research, namely research of (Yiing and Ahmad, 2009), (Vigoda-Gadot, 2007)) and (Babalola, 2016) which states that leadership style influences performance.

\section{Effect of Job Satisfaction on Employee Performance}

Job satisfaction has a negative and not significant effect on employee performance with $\mathrm{P}=0.064(>0.05)$ and value of $\mathrm{CR}(t$ count $>t$ table $(-1.855<$
1.98) and loading factor of -0.491 , this coefficient shows that increasing job satisfaction will actually reduce employee performance,

The results of SEM analysis show that job satisfaction has a non-significant effect on employee performance in the Regional Government in Gorontalo Province. This study also shows a negative influence between job satisfactions on employee performance which is characterized by a negative path coefficient. Thus it can be concluded that job satisfaction does not give a direct role to employee performance. Then the direct effect between job satisfaction and employee performance in a negative direction, does not have an indirect effect on the Regional Government in Gorontalo Province. Thus it can be concluded that the hypothesis which states that job satisfaction has a significant positive effect on employee performance is rejected or not supported by facts. The findings of this study support previous research, namely research of (Khuzaeni, Idrus, Djumahir, 2013), but refused research of (Babalola, 2016). The implication of this research is to build and improve job satisfaction which ultimately improves employee performance.

Thus employees who have high job satisfaction tend to have high work performance, and conversely those with low work performance are possible because of low job satisfaction. However, if what happens is the opposite, then the task of the leader to play a more directing role, because job satisfaction is the driving force that causes employees to work diligently, and job satisfaction will determine one's achievement. Job satisfaction as something that causes, channel and preserve a person's behavior on the likes and dislikes of his job. This is one of the requirements for the ability of a leader; a leader must be able to influence, direct and communicate with employees so that employees can improve their work performance and satisfaction. 
Job satisfaction obtained by employees must be right, because job satisfaction will affect employee performance. So that it becomes one of the tasks of a leader is to be able to provide motivation (encouragement) to employees to be able to work according to the direction given, so that from some of these opinions it can be concluded that their behavior in working to be higher in order to fulfill an expectation that is accomplishment in work because the achievement of high employee performance is partly driven by high job satisfaction.

\section{Conclusion}

Leadership style has a positive and significant effect on job satisfaction of employees, as well as on performance. The use of effective leadership style will be able to provide encouragement to someone to take action to achieve the desired goals. The leadership style of the Regional Government of Gorontalo Province has an effect on its objectives coupled with the diversity of work relationships experienced by a person, it largely determines job satisfaction and search behavior for achieving predetermined goals, so leaders are required to have an awareness of the distribution of power and authority as continuous regeneration and capacity building process. Some important things for a more effective leadership style are giving awards, job responsibilities and giving incentives. However, job satisfaction only decreases employee performance, therefore it needs to be explored further towards job satisfaction factors so that it is expected to improve employee performance. So it is recommended that policy makers as bureaucratic managers to pay more attention to job satisfaction factors in order to further improve employee performance. This research only focused on the Regional Government of Gorontalo Province, so it is expected that this research could also be developed in other fields or a wider scope and not only in Gorontalo Province because each region has different characteristics. To reduce the bias due to the use of instruments with perceptions that can be updated for the next study is to use secondary data support, but not only based on questionnaires alone, so it is recommended for further research to examine in more detail the most effective models of leadership style and job satisfaction to be applied to the organization and how effective the performance performed by employees.

\section{References}

[1] Babalola, S. S. (2016). The Effect of Leadership Style, Job Satisfaction And Employee-Supervisor Relationship On Job Performance And Organizational Commitment. Journal of Applied Business Research, 32(3), 935. https://doi.org/10.19030/jabr.v32i3.9 667

[2] Badreya Al-Jenaibi. (2014). The Impact of Leadership Style on Employee Job Satisfaction. Leadership and Policy Quarterly, 3(4), 207-226. Retrieved from http://www.untestedideas.com/journa ls.php?journal=LPQ

[3] Dale Timpe, A. (Ed.). (1988). The Art and Science of Business Management Performance. New York: KEND Publishing .Inc Published underlicence from Facts on File.Inc.

[4] Douglas, W. (2011). A-HA ! Performance. Building and Managing a Self-Motivated Workforce. PPPM.

[5] Dubrin, A. J. (1998). Human Relations: Interpersonal Job-Oriented Skills. (Latest edi). Retrieved from https://id.scribd.com/presentation/35 8346841/Chapter-1-the-Nature-andScope 
[6] Gulseren, Duygu , Kelloway, K. (2010). Structural Equation Modelling.

[7] Herzberg, F. I. (1974). MotivationHygiene Profile, Article Reseacrh Associate at the University of Utah.

[8] Kertiriasih, N. N. R., Sujana, I. W., \& Suardika, I. N. (2018). The Effect of Leadership Style to Job Satisfaction, Employee Engagement and Employee Performance (Study at PT. Interbat, Bali, Nusra, and Ambon). Management and Economics, 9(03). https://doi.org/https://doi.org/10.155 20/ijcrr/2018/9/03/468

[9] Khuzaeni, Idrus, Djumahir, S. (2013). The Influence of work Culture, Work Stress to the Job Satisfaction and Employees Performance in the State Treasury Service Office in Jakarta, Indonesia. IOSR Journal of Business and Management (IOSR-JBM), 9(2).

[10] Pervez Ghauri. Kjell Gronhaug. (2010). Research Methods in Business Studies. Financial Times Prentice Hall. Retrieved from www.personed.co.uk

[11] Siagian, P. (1999). Techniques for Growing and Maintaining Organizational Behavior. Jakarta: PT. Toko Gunung Agung. Jakarta.

[12] Vigoda-Gadot, E. (2007). Leadership style, organizational politics, and employees' performance an empirical examination of two competing models. Personnel Review, 36(5), 661-683. https://doi.org/10.1108/00483480710 773981

[13] Waldman, D. A., \& Yammarino, F. J. (1999). CEO Charismatic Leadership: Levels-of-Management and Levels-of-Analysis Effects. Academy of Management Review, 24(2), 266-285. https://doi.org/10.2307/259082

[14] Yiing and Ahmad. (2009). the moderating effects of organizational culture on therelationships between leadership behaviour and organizational commitment and between organizational commitment and job saticfaction and performance Faculty of Business and Accountancy. Leadership \& Organization Development Journal, 30(1), 53-86. https://doi.org/DOI: 10.1108/01437730910927106 